\title{
危機の中の $\mathrm{EU}$ 法
}

- EU 法秩序変容の可能性——

須 網 隆 夫

\section{I. 序}

EU（欧州連合）は，2009年以降，ギリシャ債務危機を端緒とする「ユーロ危 機（欧州金融・債務危機）」，ロシアのクリミア併合に起因する「ウクライナ危 機」，シリア内戦の勃発以後増加し，2015年に激増した大量の難民流入による 「難民危機」，そして，2016年 6 月にイギリスが国民投票により EU 離脱を決定 したことによる「Brexit危機」という複数の危機に直面してきた。そして連 続する危機を背景に，少なからぬ加盟国で，ブリュッセルの EU 官僚を批判し， 反 EU を標榜するポピュリズム政党が台頭し， EUの政治的基礎を摇るがして いる。加盟国国民の $\mathrm{EU} へ$ へ支持は，ユーロ危機以前に比べて弱まり， $\mathrm{EU}$ の 将来を悲観視する言説が $\mathrm{EU}$ の内外でもてはやされている。しかし，これらの 言説が $\mathrm{EU}$ 法について語ることはない。欧州委員会を始めとする $\mathrm{EU}$ 諸機関は, 危機の中でも EU 法を着実に制定・執行し，EU 司法裁判所も以前と変わりな く, 肃々と判決・裁定を出し続けている。確かに, 法は, 政治・経済の変化に 対して比較的強勒である。EUは，その前身である欧州共同体の設立以来，幾 多の危機を乗り越えてきたが，EUが過去に危機を克服できた一因は， EU 法 という独自の法秩序が EUを安定させていることにある。そして，EUが現在 直面する危機は，第一次的には，経済危機であり政治危機である。しかし，こ 
『日本 $\mathrm{EU}$ 学会年報』第38号, 平成30年 4 月

れだけの危機の中で，EU 法の領域だけが，その影響を全く受けない幸せな領 域であり得るだろうか。本稿は, そのような問題意識から, 危機が $\mathrm{EU}$ 法に与 える影響を検討しようとする。もし EU 法が変容すれば，それは EU 法が支え る $\mathrm{EU}$ 自体の変容に帰着する可能性が生じざるを得ない。なお, 本稿では, $\mathrm{EU}$ 条約を TEU, EU 運営条約を TFEU と表記するとともに, EU 創設以前の 時期の EC 法についても，便宜上 EU 法と呼んでいる。

\section{II . EU 法秩序の独自性と高い実効性}

\section{1. $\mathrm{EU}$ 司法裁判所の $\mathrm{EU}$ 法秩序観}

まず, EU 司法裁判所の判示から, EU 法の独自性を確認する。 EC (欧州共 同体）が設立された1950年代，加盟国が締結した国際条約を基礎とする ECが, 通常の政府間国際組織であるのか否かは必ずしも明確ではなかった。しかし欧 州司法裁判所（当時）は, 1960年代前半から, 幾つかの著名な判例で $\mathrm{EU}$ 法秩 序の特別な性質を明確にし，EU 法が国際法とは異なる独自の法秩序であるこ とを強調した。すなわち, EU 法の直接効果を確立した，1963年のVan Gend en Loos 事件先決裁定は, 「[欧州経済］共同体は, 国際法の新しい法秩序を構 築する」と判示しで， EU 法の新規性を強調したが, 翌年の Costa 対 ENEL 事 件先決裁定はさらに, 「通常の国際条約と異なり, EEC 条約は, 独自の法制度 を創出した」,「[EEC] 条約より生じる法は, 独立の法源であり, その特別か つ独自の性質のゆえに，いかなる国内法規定もこれに対抗することはできな い」と判示して，国際法との区別を明確にした。これらの判例を前提に，その 後1986年の Les Verts 事件判決は，下位法規の審査基準となる EEC 条約を 「基本的憲法的憲章 (basic constitutional charter)」と位置づけ），1991年の EEA 条約に関する意見 $1 / 91$ 号も，基本条約による新たな法秩序の創出に加えて, 「EEC 条約は，国際条約の形態で締結されているにも係わらず，法の支配を基 礎とする共同体の憲法的憲章（constitutional charter）を構成する」と述べ，基 
本条約は共同体のある種の憲法であるとの認識に到達する。このような $\mathrm{EU}$ 法 の独自性は，最近も繰り返し判示されており，現在に至るまで， EU 司法裁判 所の認識の根幹を形成している。そして学説も EU 法秩序の独自性（sui generis）を強調し，それはしばしば EU 法の「超国家性」と呼ばれてきた。

\section{2. $\mathrm{EU}$ 法の独自性の意義}

確かに EU 法は, 初期に形成された判例法の結果, 通常の国際法と異なり, $\mathrm{EU}$ 法の直接適用性と直接効果を媒介にして国内法と融合し， EU 司法裁判所 だけでなく，加盟国の行政機関・国内裁判所でも，矛盾する国内法を排除して 適用される法秩序へと発展した。それ以後, このような $\mathrm{EU}$ 法は, 通常の国際 法以上の高い実効性を発揮して，欧州統合の政治的成果を固定し，統合への政 治的推進力が失われた時期にも，統合の成果が後退することを防いできた。 $\mathrm{EU}$ 法の高い実効性がなぜ実現したのか, 特に加盟国が EU 法の国内適用を受 け入れるに至った理由は, 政治学の立場から様々に説明されているが, 法的に は，EU 法が国際法から区別されたことが一因であったと考えられる。例えば， 前述の Costa 対 ENEL 事件では，実質上同一の争点が，イタリア憲法裁判所 によって先に判断されていた。すなわち憲法裁判所は，1964年 3 月， EEC 条 約批准法と同事件の争点であった電力事業国有化法の抵触を, 「後法は前法を 破る」の原理に従って処理し, EEC 条約違反の国内法を違憲無効としなかっ た。イタリアは, 国際法と国内法を峻別する二元論の国であり, 国際条約は, 国内法に変型又は編入されるまでは国内的に効力を有しないところ，憲法裁判 所は，EEC 条約を通常の国際条約と同様に扱ったのである。これに対し，憲 法裁判所判決を受けた，同年 7 月の先決裁定は，前述のように EEC 条約と通 常の条約との相違を強調した。この経緯に照らせば，裁定による条約との相違 の強調は, イタリア裁判所に向けられたメッセージである。要するに, EU 法 が国際法でなければ，二元論の適用を排除できる可能性が論理的に生じる。先 決裁定は, 国内裁判所に，これまでの国内法理論と整合的に EU 法の優位を受 
『日本 $\mathrm{EU}$ 学会年報』第38号, 平成30年 4 月

容できる論理を示唆したのである。イタリア憲法裁判所は, その後徐々に EU 法の優位を承認していくが，そこでは，EU法の性質への直接的言及こそ見ら れないが, Costa 対 ENEL 事件判決のような二元論を前提とした主張は影を 潜めていく。

\section{EU 法と国際法の区別}

もっとも, $\mathrm{EU}$ 法の独自性を, 加盟国の国内裁判所が $\mathrm{EU}$ 司法裁判所と同様 に認めたわけではない。多くの国内裁判所が， EU 法の優位の承認に際して， 加盟国憲法を根拠とする等，EU 司法裁判所の理由付けを採用せず，また加盟 国憲法との関係で優位に限界を設定していることは, それを示唆している。

学説上も, EU 法と加盟国法の関係については論争が続いている。 EU 法と 国際法の区別を批判する Hartley は，2001年の論文で，再度国際法との区別を 問い，基本条約を頂点とする $\mathrm{EU}$ 法秩序は国際法の一部であると指摘する。

Hartleyの議論は，EU 法が，その有効性を加盟国間の設立条約締結と加盟国 憲法に従った批准に依拠する以上, 自律性を欠くことを出発点とし, その論理 は, 既存の法概念に基づく限り, 相応の説得力がある。しかし Hartley の見解 は一般化せず，多くの EU 法研究者は，EU 司法裁判所の判例に従って国際法 との相違を前提とする。彼らは, EU 法をめぐる法現象は, 国際法現象として は説明しきれないと判断して，EU 法秩序と加盟国法秩序の関係を説明するた めに，多様な議論を展開してきた。既存の法枠組・法概念を前提とする限り， Hartleyの議論はおそらく正しい。しかし EU 法の発展により生じた新たな法 現象の下で，それらの妥当性自体が問われている。そのため, Hartleyの議論 に無条件に賛同することはできない。もっとも，EU 法優位の一元的な連邦的 法秩序像に拘泥せず，EU 法の絶対的優位の貫徹に柔軟に対応する「憲法多元 主義 (Constitutional Pluralism)」が有力に主張されていることは, EU 法と国際 法の完全な峻別に疑問も生じさせている。物理的強制力を有する権力が, 加盟 国レベルにしか存在しない現状の下で，集権化された強制力に支えられていな 
い点で, EU 法と国際法の間には重要な共通性があるからである。そうである からこそ，グローバル社会への立憲主義の適用を議論する「グローバル立憲主 義」論は，しばしばEUの立憲主義を参照するのである。要するに，EU 法と 国際法は区別されながらも連続し，両者は一定の距離を置きながら，国内法を 含めた三者間にある種の均衡状態を維持してきた。その均衡に影響を及ぼしか ねない事態が，EUの危機の中で進行しつつあるのである。以下，ユーロ危機 と難民危機について，それぞれ検討する。

\section{EU 法と国際法の混淆}

\section{1. ユーロ危機への対応措置}

$\mathrm{EU}$ 基本条約は，経済通貨同盟（EMU）によって導入された共通通貨ユーロ の安定のために，加盟国に厳格な財政規律を課しているが，ギリシャは基準を 超える政府債務を蓄積し，しかも政府は，その財政赤字を過少申告していた。 この粉飾の発覚により，2009年10月，「ギリシャ債務危機」が発生し，それが 他の加盟国をも巻き込み「ユーロ危機」に発展した。EU内では, 危機発生後, EMU 開始後10年間の経験と失敗から, 経済ガバナンスの改善が必要であると いう共通認識が短期間に形成された。EUが排他的権限を有する通貨政策分野 (TFEU 3 条 1 項(c)）と異なり，EU 権限が加盟国の政策調整に限られる経済政 策分野では (同 5 条 1 項), EU の権限は弱く，他方政府間協力による対応の実 効性の程度は当初より懸念されていた。そのため危機発生後, そのような EMUの制度的欠陥を改革する必要性について, EU 内の認識は概ね一致し, 基本条約は TFEU 136条を除き改正されていないものの, その枠内で, 加盟国 の財政規律・債務危機の両面において多くの対応措置が採られた。それらの措 置による改革は 4 つの柱から成る。第一は, 資金不足で債務不履行の危機に陷 った加盟国に資金を供給する財政支援制度，第二は，危機の原因となる過剰赤 字の発生を防ぐための加盟国の財政規律を強化する EU 立法, 第三は, やはり 
『日本 $\mathrm{EU}$ 学会年報』第38号, 平成30年 4 月

危機予防のための加盟国のマクロ経済不均衡の監視・是正のための $\mathrm{EU}$ 立法, そして第四は，EU 内の金融機関の健全性維持のための実効的な銀行監督制度 と，それを支える破綻処理・預金保護制度を内容とする「銀行同盟」である。 なお EU 立法の多くは，直接適用性を有する規則の形式を採用している。これ らの諸措置により，加盟国の経済・財政政策に対する EUレベルの規律は格段 に向上し，その結果，不透明さを内包しながらも，単一通貨ユーロは，現在ま でその安定を失わずにいる。しかし他方で，ユーロ危機対応措置には，以下の ように，EU 法と国際法の区別に影響を生じかねない要素が含まれていた。

\section{2. $\mathrm{EU}$ 法と国際条約の結合}

（1）危機対応措置の特徵

ユーロ危機対応措置の特徵は, その一部が, $\mathrm{EU}$ 立法である規則・指令と加 盟国間の条約（基本条約と区別するために「国際条約」とする）を組み合わせた， 複雑な構造を採用したことである。第一に，加盟国への財政支援制度として， 簡易改正手続による TFEU 136条の改正を経て，ユーロ圈加盟国（当時17カ国） は, 2012年 2 月，「欧州安定メカニズム (European Stability Mechanism, ESM) 設立条約」に署名し，ESM は同年10月に発足した。 ESM の設立により加盟国 への財政支援は恒久化し，ESM は，欧州中央銀行（ECB）から資金供給を受 け，最大5000億ユーロまで加盟国に融資できる。第二に，加盟国の財政規律に 対する基本条約の規制は, 1996年の「安定成長協定 (Growth and Stability Pact)」によって補強されていたが, 危機発生後, 協定の内容を強化するため に, 多くの EU 立法が採択され, さらに2012年 3 月, 加盟国の財政安定と財政 規律の強化を目的として, 政府間協定である「安定・協調・ガバナンスに関す る条約（TSCG）（財政条約）」が，加盟国（イギリス・チェコを除く25力国）間で締 結された。加盟国が，前述の ESM から財政支援を受けるためには，本条約の 批准が必要であり, ESM 条約と財政条約は実際上一体化している。 
（2）加盟国間で締結される国際条約の利用

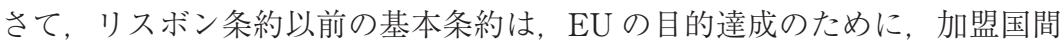
で締結される国際条約を用いることを，EUの枠外又は周辺部分に関する事項 及び政府間協力の実質を有する第三の柱の領域につき予定していた (EC 条約 293 条，旧 $\mathrm{EU}$ 条約 34 条 2 項)。リスボン条約により，それらの規定は改正され，国際 条約への明示的言及は消えたが，学説は，な技その可能性を肯定している。 $\mathrm{EU}$ が共有権限を有する領域では EU 立法が利用できるので, 従来も国際条約の利 用はなく，今後もその可能性は低い。しかし EMU，特に経済同盟の分野では いささか事情が異なる。第一に，前述の TFEU 136条 3 項が，加盟国間の国際 条約による財政支援制度の創設を認めている。第二に，加盟国の経済政策に関 する EU 権限は，共有権限に分類されてはいるが（TFEU 4 条 1 項），その実質 は，理事会の定めるガイドラインによる加盟国経済政策の調整に止まり（同 5 条 1 項），従来の第三の柱と類似している。従って，ESM 条約・財政条約のよ うに, EMU の在り方を, EU 法の枠外の国際条約が補完する構造は変則的で はあるが，考えられない対応ではない。しかし，国際条約に依拠する危機対応 には懸念がある。それは, リスボン条約が定める $\mathrm{EU} ・$ 加盟国間の均衡を変化 させかねないだけでなく， $\mathrm{EU}$ 枠外の条約により $\mathrm{EU}$ 機関に一定の役割が担わ せる場合には，EUとの間に緊張関係も生じるからである。加盟国間条約によ り，EU 機関に加盟国間の調整を依頼することは一般には禁止されず， $\mathrm{EU}$ 司 法裁判所もそれを肯定しているが，そこでは全加盟国の合意が前提とされてい た。他方，危機対応措置では，ユーロ圈加盟国だけが $\mathrm{EU}$ 機関を利用している。

国際条約，特に一部の加盟国間で締結される国際条約の利用は，政府間主義 が超国家的統合を支えるという現象であり，新たな形態の EU 法の誕生ではな いかとも指摘される。このような議論が現れること自体, 国際条約の利用が, これまでの EU 法秩序の在り方を変容させる契機を含んでいることを示してい る。前述のように，国際条約の利用により， EU 法上，幾つかの問題が発生す るが，本稿の主題に関連する，EU 法と国際条約の併用による EU 法秩序への 
『日本 $\mathrm{EU}$ 学会年報』第38号, 平成30年 4 月

影響を，財政条約についてさらに検討する。

(3) EU 法と国際条約の一体化

本稿が注目する現象は，EU 法と国際条約が融合し，一体となって EMUを 支える構造である。財政条約の内容を検討すると，その大部分は，基本条約を 始めとする既存の $\mathrm{EU}$ 法の内容と深く関連し, 基本条約による EMUを補強し ている。財政条約が EU 法に従って解釈・適用されることも(TSCG 2 条 1 項), 両者の密接な関係を示している。

そのような財政条約の法的性質をどのように理解すべきであろうか。国際法 であるのか，EU 法であるのかという問いである。財政条約は，厳密には $\mathrm{EU}$ 法ではない。国際条約である財政条約には，EU 法のような高度の規制は及ば ず，財政条約違反に対して，直接効果・加盟国の損害賠償責任など, $\mathrm{EU}$ 司法 裁判所が形成してきた判例法理は適用されない。しかし財政条約は，完全に $\mathrm{EU}$ 法の外にある法秩序でもない。義務違反訴訟類似の手続を財政条約自体が 規定しており (TSCG 8 条)，EU 司法裁判所への訴訟提起は可能である。さら に, 財政条約と基本条約の内容は相互的な補完関係にある。基本条約を国際条 約が補完する例としては，一部の加盟国が域内国境規制の廃止を目指した，シ エンゲン協定（1985年）・シェンゲン実施条約（1990年）があった。しかし，財 政条約をそれらと同視はできない。シェンゲン協定・条約の対象である域内国 境管理は, 人の自由移動と密接に関連するとは言え, 当時の $\mathrm{EC}$ 条約は, 国境 規制の全面的廃止までを加盟国に求めては抢らず，その内容は基本条約以上の ものであった。これれに対して財政条約は，EMUに関する基本条約・EU立法 の諸規定と密接に絡み合っている。すなわち，一方で基本条約は財政条約によ り補完されている。そうであるからこそ，財政条約により，発効後 5 年以内に， $\mathrm{EU}$ の法的枠組（基本条約）に，財政条約の内容を組みこむことが求められて いる (TSCG 16条)。しかし他方で，財政条約にも EU 法による補完を予定する 部分がある。すなわち, 財政条約は, 過剩赤字手続対象国による財政・経済連 携プログラムの導入を規定するが，その内容は EU 法によって与えられる（同 
5 条 1 項)。このような相互補完の結果, 財政条約と EU 法は分離不可能となり, 事実上両者は一体化し，それゆえ，EU 司法裁判所の管轄が財政条約にも及ぶ のである (同 8 条)。

\section{3. 国際条約との一体化による $\mathrm{EU}$ 法秩序の変容}

このような財政条約との一体化により，EU 法秩序はどのような影響を受け るのであろうか。一連の危機対応措置により，ユーロ制度は，ほとんど新たな 制度にまで作り直されたと評価される。その変化は, 従来の基本原則からの逸 脱が適法と承認され，違法・合法を論じることにもはや価值はないという意味 で憲法的変容であり，危機対応措置に起因する変化は，ユーロを超えて EU 全 体にまで及んでいるとも指摘される。

そのような大規模な変化の中で，本稿の観点からは，ESM 条約・財政条約 が示すように，危機対応措置の文脈で，EU 法と国際法が結合されたことが重 要である。なぜなら, 基本条約と加盟国間の国際条約の結合は, 本質的に, $\mathrm{EU}$ 法の超国家性を動摇させ，前述のような $\mathrm{EU}$ 法と国際法の峻別に基づく, $\mathrm{EU}$ 法の性格規定を変容させかねないからである。それは, EMUの自律化が, $\mathrm{EU}$ の法的・制度的統一性を弱めるからではない。むしろ, 財政条約が示すよ うに，国際法と超国家法である EU 法の密接な接合により，両者の性質的相違 が不明確となり, $\mathrm{EU}$ 司法裁判所が強調し, また多くの学説も立論の前提とし てきた，EU 法と国際法の本質的相違への疑念が生じるためである。そもそも， 伝統的な国際法と EU 法の中間に位置する EEA 法が， EU 法に近い実効性を 有することが示すように，国際法と完全に切断された超国家法としての EU 法 という EU 司法裁判所の認識には，額面通りには受け取れない部分があった。 確かに EU 法が通常の国際法から峻別されたことにより，国際法の諸原則は， $\mathrm{EU}$ 法秩序内部には適用されず，加えて国際法に関する国内判例も $\mathrm{EU}$ 法に適 用されない可能性が生じて, EU 法の自律的発展への道が開かれた。しかし， そのことは，EU 法が国際法としての性質を全て失ったことを必ずしも意味し 
『日本 $\mathrm{EU}$ 学会年報』第38号, 平成30年 4 月

ない。加盟国政府・国内裁判所など加盟国機関の協力なしには, 加盟国内で $\mathrm{EU}$ 法が適用され得ないことが示すように，その執行に集権化された強制力を 欠く EU 法は，国際法的な色彩の強い法執行システムにな挔存しており，国 際法と同じ特徵を有している。この特徵は, 1990年代後半以降, 多くの加盟国 憲法裁判所が， EU 法に対する加盟国憲法の優位を部分的にせよ肯定する事態 が定着する中で，より明確になってきた。そしして財政条約は，国際法と共通す る部分がある EU 法の本質を別の形で示したのである。国際条約との結合は, 確かに EMU の EUの他の部分からの差異化を意味するとも理解できるが，逆 に EU 法の超国家性の意味を問い直しているとも考えられる。近時, ユーロ危 機への対応措置だけでなく，その他の場面でも国際条約（例）統一特許裁判所 条約）の使用が目立つが，超国家主義と政府間主義は中身のない区別ではない かとの疑問の提示に根拠がないわけではないのである。そして, EU 法と国際 法の区別の相対化は, 両者の相違を前提に成立している $\mathrm{EU}$ 法の高い実効性に 否定的影響を生じさせるかもしれないことに注意が必要である。EU 法は，国 際法と異なる超国家法であるからこそ, 国際法より高い実効性を保つことがで きていると考えられ，実際にも多くの加盟国で，EU 法は国際法とは異なる存 在と認められている。これまでの $\mathrm{EU}$ の歴史を見る限り, EUの枠外で発展し た加盟国間協力は，その後の基本条約改正により， $\mathrm{EU}$ の枠内に組みこまれる のが通例である。今回も, 財政条約が予定するように (16条), 財政条約の内 容の基本条約への編入が完成すれば，EU 法の独自性は再度確立される。しか し，財政条約と EU 法が一時的にせよ，前述のような関係を構築できた事実は， $\mathrm{EU}$ 法の性質を検討する上で，引き続き考慮されざるを得ないであろう。

\section{EU 法への加盟国の反抗}

\section{1 . 難民危機への対応措置}

ユーロ危機が小康状態を保っていた2015年，EUは新たな危機に直面する。 
それがシリアを始めとする域外第三国からの大量の難民流入による「難民危 機」である。2013年頃から，域外国境を抱える加盟国で難民申請数が増加して いたが，2015年には，難民の流入は爆発的に増加し，EU 及び加盟国はその対 応に追われた。域内に拈ける人の自由移動を目的とする EUは, 「自由・安 全・正義の領域」の一部として，共通庇護政策を発展させてきた。庇護政策の 中心は，1990年に締結された，ダブリン条約（1997年発効）を中核とする「共 通難民システム」であり，難民危機発生時には，2013年 6 月採択の「ダブリン III 規則」が適用されていた。同規則は, ダブリン条約の原則を継承し，域内 での重複申請を回避するために，第三国国民等の庇護申請は単一の加盟国が審 査し，審査責任国は，不正規越境者の場合， $\mathrm{EU}$ 域内で最初に入国した加盟国 であると規定している（同規則 3 条 1 項， 13 条 1 項）。そのため, 域外国境を有す る加盟国への負担集中は不可避であり，バルカン・ルート，地中海ルート双方 からの難民流入により，特にギリシャ・イタリアの両国に負担が集中し，共通 庇護政策の欠陥が露になってしまった。

難民危機発生後，一部加盟国への難民流入に抜本的に対応するために，ダブ リン・システムの改革が提案されたが，それとは別に，危機に対する直接的対 応として採用された措置が, ギリシャ・イタリアより他の加盟国への難民の移 送である。難民危機が深刻化しつつあった2015年 6 月，欧州理事会は「連帯と 責任の公平な分担の原則」（TFEU 80条）に従い，難民流入の最前線に立つイ夕 リア・ギリシャを援助するために，国際的保護の必要性が明確である 4 万人を 他の加盟国に再配置 (relocation) することを全会一致で決定した。そして そし, 再 配置を実施するために，同年 9 月，閣僚理事会は，難民の域内での移送を定め る複数の決定（いわゆるリロケーション決定）を採択した。第一は，9月14日に 採択された, イタリア・ギリシャからの再配置のための「理事会決定 2015/1523号」であり，同決定は，イタリア・キリシャで庇護申請した難民の うち 4 万人を他加盟国に移動させることを定めた（同決定 4 条）。但し同決定は, 加盟国ごとの受入れ人数は定めておらず，引き続き第二の決定である「理事会 
『日本 $\mathrm{EU}$ 学会年報』第38号, 平成30年 4 月

決定2015/1601号」が, 同月22日に採択された。同決定は, 他加盟国に移動さ せる申請者数を 12 万人に引上げた上で, 移送に 2 年間の期限を設定し, さらに 6 万 6000 人について，加盟国ごとの受入れ人数を具体的に特定した（同決定 4 65)

条 1 項, 附属書 I 及び II)。例えば, 後述するハンガリーの場合, イタリアから 306 人，ギリシャから 988 人の受入れが義務付けられている。

このリロケーション決定に対して, 現在, 一部の加盟国が公然と反抗する事 態が生じており，EU法の特徵である，加盟国内で確実に適用される $\mathrm{EU}$ 法の 高い実効性が損なわれている。そこには, ユーロ危機の場合と似て, 一部加盟 国の EU 法不遵守が, システム全体の存続に影響する事態が見られる。

\section{2. $\mathrm{EU}$ 法の不遵守と $\mathrm{EU}$ の基本的価値の侵害}

(1)リロケーション決定と中東欧諸国

前述の理事会決定2015/1601号は，特定多数決により，一部加盟国の反対を 押し切って採択された。中東欧の $\mathrm{EU}$ 加盟国には決定案に反対する国が少なく なく，ハンガリー，チェコ，スロバキア，ルーマニアの各国は反対票を投じ,

フィンランドも茟権した。そしてハンガリーとスロバキアは，2015年12月には, 同決定の無効を求めて, それぞれ EU 司法裁判所に訴訟を提起した。特にハン ガリーでは，国会が政府の方針を全面的に支持し，同年11月には，難民の義務 的受入反対法を制定して，政府に無効訴訟の提起を義務付けた。その後もハン ガリー政府は，移民受け入れ反対を積極的にキャンペーンし，国民に EU 庇護 政策の不当性を訴え続け，一貫して同決定の実施に抵抗している。

同決定に基づく難民の再配置は全体としては徐々に進み，2017年に入ってか らは，毎月の移送人数も増加して，2017年 7 月までに， 2 万 4600 人以上（ギリ シャから 16,803 人，イタリアから 7,873 人）の移送が完了し， 9 月の期限までの全 員の再配置を目指して努力が継続された。多くの加盟国は, 決定の実施に積極 的に協力しているが，消極的な加盟国もあり，特に前述のハンガリーとポーラ

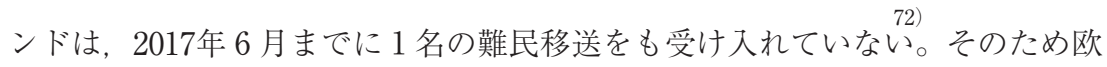


州委員会は，同年 6 月，ハンガリー，ポーランド両国に，チェコを加えた 3 カ 国に対して，TFEU 258条に基づく義務違反手続を正式に開始した。委員会の 度重なる是正要求にも係わらず，各国が違反行為を是正しなかった結果であ る。共通庇護政策が，加盟国間の「連帯と公正な責任の分担」を基礎とする以 上 (TFEU 80条), 委員会は, 他の加盟国が負担を受け入れている状況の下で, 3 力国の違反をこれ以上放置できなかったのである。しかし，3 カ国はなお違 反を是正せず，委員会は，翌 7 月には，理由付き意見書を各国に送付し， 1 か 月以内の違反是正を再度求めた。

他方， EU 司法裁判所は，2017年 9 月，前述のハンガリー・スロバキアによ る無効訴訟を併合して判断し, 原告らの主張を全て退けて, 請求をいずれも棄 却した。しかし, この判決後も, ハンガリー, ポーランド, チェコの 3 カ国は, 依然として難民の受入れを拒否し続けた。このため欧州委員会は, 同年12月， 各国に対する義務違反訴訟を $\mathrm{EU}$ 司法裁判所に提起した。さで, リロケーショ ン決定へのハンガリー・ポーランド両国の否定的態度は, より広い文脈で検討 する必要がある。それは, 両国は近時，EUの依拠する基本的価值をめぐって $\mathrm{EU}$ と深刻な対立関係に入っており，難民受入れ問題も，そのような緊張関係 と無関係ではないからである。以下，ハンガリーより検討する。

(2) ハンガリーの憲法状況の変化

ベルリンの壁の開放以前に政治改革が開始されていたハンガリーでは, 1949 年憲法 (ハンガリー人民共和国憲法) を改正した1989年憲法の下，1990年代に入 り, 強力な一院制議会による議会制民主主義が再開されだ。その後ハンガリー は $\mathrm{EU}$ 加盟の準備に入るが， $\mathrm{EU}$ 側は，加盟に際して，基本的人権，民主主義 の確立を要求する「コペンハーゲン基準」に照らした国内制度の改革を要求し, ハンガリーもそれに応えて国内改革を進めだ。そのような $\mathrm{EU}$ とハンガリーの 協力的関係は, 2004年の EU 加盟実現後も継続した。例えば, 中東欧で最も成 功した憲法裁判所と評されたハンガリー憲法裁判所は, $\mathrm{EU}$ 加盟後, 親 $\mathrm{EU}$ 的 態度を示し， EU 法の優位に配慮して，憲法に照らして $\mathrm{EU}$ 法を直接には審査 
『日本 $\mathrm{EU}$ 学会年報』第38号, 平成30年 4 月

しない慎重な態度を維持していた。またた最高裁判所も, 国内裁判所は EU の裁 判所であると判示して, EU 法の直接適用可能性, EU 法の優位・直接効果を 受入れ，それらは国内裁判実務に定着していた。

しかし，2010年 4 月の総選挙により，フィデス = ハンガリー市民連盟・キリ スト教民主人民党が政権を掌握し，第二次オルバン政権が誕生したことにより 事態は一変する。政権与党が憲法改正に必要な, 国会の総議員の 3 分の 2 を超 える議席を獲得したため, オルバン政権は, 2010年以降, 頻繁に憲法改正を実 施し，2011年 4 月には，それ以前の改正も反映させた新憲法であるハンガリー 基本法を制定したが, その後, 基本法も数次にわたり改正されている。なお新 憲法は, わずか 9 日間の国会審議で採択され, 内容以前に, 野党を排除し, 国 民的な議論にも基づかずに起草された制定手続が批判されている。

新憲法制定を含む10数度にわたる憲法改正の全容を紹介することは紙幅の制 約によりできないが, 憲法に加えて, 憲法付属の「暫定条項（Transitional Provisions)」，憲法改正と類似した出席国会議員の 3 分の 2 の賛成を要する「重要 法（Cardinal law）（3 分の 2 法）」の制定及び法適用の実務により，ハンガリー では, 議会権限が絶対的に強化されるとともに, 憲法裁判所を始め, 議会に対 するあらゆる対抗権力が弱体化され，法の支配，民主主義，基本的人権の保護， そして立憲主義に深刻な懸念が生じている。要するに，一連の憲法改正の結果， ハンガリーは, 中央集権化された行政に権限が集中し，権力に対する抑制と均 衡が存在しない, 権威主義的な非立憲的政治体制に転換してしまったと広く認 識されている。確かに, 司法部を見ても, 憲法裁判所を中心とする司法の独立 への攻撃は顕著であった。主な点を要約すると, 第一に, 憲法改正により, 憲 法裁判所の違憲審査権限が制限されて，その地位が低下させられたとともに， 裁判官の任命方法・定員, 長官の任命方法が変更され, 政権党の影響力が増大 している。第二に, 通常裁判所についても, 裁判官の任命方法の変更等によっ て議会の影響力を強化する改革が行われるとともに, 暫定条項により, 通常裁

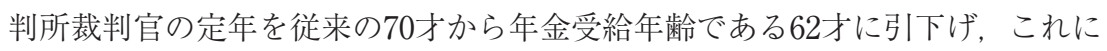


より 300 人近い練達の裁判官が退職を余儀なくされ，裁判官の身分保障が危ぶ まれた。第三は，より直接的な裁判官人事への介入である。欧州人権裁判所大 法廷は, 2016年 6 月, 元同裁判所裁判官であり, その後ハンガリー最高裁判所 の長官であったBaka が，与党が企図した司法改革を批判したために任期途中 で事実上解任されたことにつき，欧州人権条約 6 条 1 項及び 10 条違反を認定し 89)

ている。そして第四は, 憲法裁判所が違憲無効と判断した法律の内容を憲法改 正によって基本法に取り込むことによって違憲審査を無意味化したことであり， これにより，憲法の保護者としての憲法裁判所の役割は著しく損なわれた。

(3) $\mathrm{EU} の$ 基本的価值との相克

以上のようなハンガリー憲法体制の変容は，EUの基本的価值との深刻な抵 触を惹起している。 EUは, 民主主義, 法の支配, 人権尊重等の基本的価值の 共有を基礎とする団体であり（TEU 2 条），基本的価值を尊重するヨーロッパ 国家だけが EUに加盟できる (同49条)。これらの価值は, 広く承認される普遍 的な価值であるので，ハンガリーで進行する事態には，EUだけでなく，様々 な国際機関が対応に乗り出している。特に欧州審議会は積極的であり，その 「法による民主主義のためのヨーロッパ委員会」（通称ベニス委員会）は，当初よ り, 憲法改正・基本法制定を, 欧州人権条約とともに欧州審議会構成国が共有 する民主主義・法の支配の基準に照らして評価し，再三意見を公表して，ハン ガリー政府に修正を勧告してきた。特に2012年以降の意見は批判の程度を強め, 例えば，司法に係る改革は，司法の独立に関するヨーロッパ基準に反するだけ でなく，公正な裁判を受ける権利（欧州人権条約 6 条）にも違反すると指摘して いる。ハンガリー政府は, 前述のBaka 事件判決への対応が示すように, 欧州 審議会との対話を全面的に拒否はせず，部分的には譲歩をみせるが，その譲歩 は必ずしも十分でない場合も多く，新たな紛争が発生する懸念は尽きない。

他方で EUは，欧州議会の決議に続き，欧州委員会が，オルバン政権による 制度改革が EU 法に抵触する限り，個々に義務違反手続を開始して対応し， $\mathrm{EU}$ 司法裁判所により義務違反が認定されると, ハンガリーもそれなりに違反 
『日本 $\mathrm{EU}$ 学会年報』第38号, 平成30年 4 月

を是正してきた。例えば，2017年にも，外国から資金を得ている NGO に関す る法律に対して, 欧州委員会は, $\mathrm{EU}$ 基本権憲章違反等の理由で義務違反手続 を開始している。しかし，義務違反手続では，法の支配・基本的人権に対する 懸念に正面からは対応できず，より包括的な対応が必要である。ここで留意す べきは，EU 条約が，基本的価值の共有を定めた結果， EU と加盟国間には特 別な関係が成立しており，EUは，加盟国に最低限の立憲的同質性を要求でき ることである。 EUは, 加盟前の段階では，加盟申請を留保することにより， 中東欧の加盟候補国に EUの価值を強制することができたが, 加盟後も, 新規 加盟国に基本的価值を引き続き遵守させる必要がある。そのための制度が, TEU 7 条の基本的価值に反する加盟国に対する制裁手続である。基本的価值 違反に対する制裁手続は, 理事会による,「深刻な違反の明白な危険」の認定 によって開始する（TEU 7 条 1 項）。ハンガリーの新憲法体制は, 2017年 5 月 の欧州議会決議が,「基本的価值の深刻な違反」を指摘したように，多くの点 で $\mathrm{EU}$ の基本的価值と整合せず，法の支配の基礎が損なわれ，基本的価值の 「深刻な違反の明白な危険」があると考えられる。もっとも制裁手続は, 過度 に制裁的であり，かえって事態を悪化させるとの懸念もあり，その実効性には 疑問もある。そのため委員会も, 制裁手続の発動要件が満たされる前に, 基本 的価値への脅威を除去することを目指す，「新たな枠組み」を打ち出していた。 しかし, 前述の欧州議会決議は, 制裁手続の開始に積極的であり, 今後の推移 が注目される。

(4) ポーランドの基本的価值違反に対する制裁手続

ところで，制裁手続の適用が議論されているのはハンガリーだけではない。 前述のように難民受け入れに抵抗するポーランドでも，2015年以降，基本的価 值違反の事態が出現している。ポーランドでは, 2015年10月, 法と正義党によ る政権掌握直後から, ハンガリーと類似の非リベラル体制が構築され, 特に政 府が, 憲法裁判所の権威を無視するという法の支配に正面から反する事態が起 きている。欧州委員会は, 前述の「新たな枠組み」により, ベニス委員会とと 
もに，直ちにポーランド政府との接触を開始し，2016年 7 月には，違憲審査が 実効的に機能しておらず，法の支配への全体的脅威が存在すると認定して，憲 法裁判所による違憲審査の実効性回復を勧告した。委員会との対話の中で，ポ ーランドが改善した部分もあるが, その範囲が限定的であるだけでなく, 勧告 後も, ポーランド政府は憲法裁判所判決を無視して, 憲法の最終判断者である 憲法裁判所の地位を否定し続け，委員会勧告にも全面的拒否を回答した。その ため委員会は，2016年12月に補足勧告を出し，7月の勧告に加えて，さらに追 加の措置を勧告したが，政府は，依然として勧告の実施を拒否した。その後 2017年 5 月，初めてポーランドにおける法の支配を議論した理事会は，対話継 続の重要性を強調するに止まったが，委員会は 7 月に至り，裁判所関連法の制 定について 3 度目の勧告を出し, 最高裁判所裁判官を解任した場合, TEU 7 条の制裁手続を発動することを初めて明確に示唆した。そして委員会は, 12月, ついに「法の支配の深刻な違反の明白な危険」が存在することを認定し, 理事 会が明白な危険の存在を決定するよう提案した。最終的な制裁実施には, 欧州 理事会の全会一致が必要であるので，制裁実施にまで至る可能性は低いものの, 委員会が手続発動を始めて提案した意義は大きい。

このようなポーランドでは, 最近, EU 司法裁判所の判断の不遵守も目立つ。 ポーランド政府が，2016年に認可した，ユネスコ世界遺産である原始林の大規 模伐採計画に対して，欧州委員会は，環境保護指令違反を理由に義務違反訴訟 を提起し，伐採の即時中止を求めて，暫定措置（TFEU 279条）を EU 司法裁判 所に申請し, 裁判所は2017年 7 月に伐採の差止めを命じた。しかしポーランド は依然として伐採を停止していない。

\section{EU 法秩序の実効性への影響}

いかなる法秩序に扔いても，法は常に遵守されているわけではない。その意 味で, 違法行為の存在は, あらゆる法秩序に必然的に付随する現象である。 $\mathrm{EU}$ 法もその例外ではなく，その建前とは別に，常に加盟国内で遵守されてい 
『日本 $\mathrm{EU}$ 学会年報』第38号, 平成30年 4 月

るわけではない。このことは, 毎年, 多くの義務違反手続が開始されているこ とが示している。そして EU 法の場合も，加盟国の EU 法違反行為それ自体は, $\mathrm{EU}$ 法秩序にとって深刻な劦威ではない。加盟国が, 自己の EU 法違反を規範 からの逸脱として認識する限り，EUに法を強制する物理的力が備わっていな くても, 国内裁判所の協力が得られる限り, 一定の時間はかかるにせよ, 最終 的には違反行為の是正を期待できるからである。したがって, ハンガリー・ス ロバキアの場合のように，難民受入れをめぐる加盟国間の政治的対立が, EU 司法裁判所で法的紛争として処理されることは, 法の支配の観点からはむしろ 積極的に評価できる。リロケーション決定に対する無効訴訟の提起は, 両国が 下される判決に従う限り，EU司法裁判所の正統性と超国家システム内の法の 支配を強化すると考えられるし，両国が主体的に訴訟を提起したことは，EU 司法裁判所の判断に従う意思があるとも推測できるからである。

しかし他方で, ハンガリー・ポーランドの EU 法違反行為を通常の違反行為 と同一視することもできない。それは, 加盟国の $\mathrm{EU}$ 法違反が, $\mathrm{EU}$ の基本的 価値をめぐる対立に起因する場合には, 通常の違反とは, いささか事情が異な るからである。第一に, そもそも加盟国の依拠する価值が, 従来の基本的価值 の理解と根本的に異なった場合, 個別的な EU 法違反とは別に, そのような加 盟国の価值が, TEU 2 条の基本的価值の理解自体に影響を及ぼすのか, また その価值が加盟国憲法に組み込まれていれば, 基本的価值の尊重と加盟国の国 家的同一性の尊重（TEU 4 条 2 項）の関係を如何に解釈すべきか等, より根本 的な論点が生じる。第二に, この場合, 加盟国は, EU 法違反を自らが負う法 的義務の違反としてよりも，正当な権利行使の結果と理解する。換言すれば, 加盟国の信奉する価值に照らせば， EU 法違反との認定は誤った価值に基づく 結論であることになり，加盟国には，もはや違反行為を是正する動機が生じな い。前述のように, ハンガリー・ポーランドの違反行為の少なくとも一部は, 確信に基づく $\mathrm{EU}$ 法への公然たる挑戦である。そうであれば, 両国が, 欧州委 員会の再三の勧告に従わないのは当然である。第三に, 加盟国の基本的価值違 
反が，法の支配に関して生じ，司法の独立，司法判断の尊重等が損なわれる場 合，事態はさらに深刻である。EU 法の高い実効性は，加盟国の国内裁判所の $\mathrm{EU}$ 法への協力的態度に依存する部分が大きい。加盟国政府が $\mathrm{EU}$ 法に違反し ても，国内裁判所が， EU 司法裁判所の判例法理に従って， EU 法を国内法に 優先して適用する限り，EU 法は高い実効性を維持できる。要するに，加盟国 に打ける司法の独立は，EU 法の実効性を担保する前提条件である。それゆえ に, 加盟国の司法部, 特に憲法裁判所・最高裁判所等の最上級審が独立性を失 い，加盟国政府に従属せざるを得なくなると，実効性を支えるメカニズムが機 能不全に陥る恐扏が生じるのである。

ハンガリー・ポーランド両国政府が，ある種の反 EU キャンペーンを国内で 展開している状況下で，両国の EU 法遵守への意欲は一般的に低下しているか もしれない。現状では，EUとの泳刻な緊張関係にも係わらず，ハンガリー・ ポーランドに対して開始される義務違反手続の数は決して少なくはないものの, 加盟国平均から極端に乘離しているわけではない。しかし今後, 難民, 人権, メディアの多元性等, 基本的価值の理解と関連し得る分野の EU 法について違 反行為が増加する可能性は否定できず，前述のポーランドの森林伐採事件に見 るように，それらの分野だけでなく，一般的な EU 法の遵守にも悪影響が生じ る危険性もある。他方，そのような懸念に反して，引き続き $\mathrm{EU}$ 法が順調に遵 守される可能性もある。いずれにせよ, 前述の無効訴訟判決への対応とともに, 両国における EU 法の今後の適用状況を注意深く見守る必要があろう。

\section{$\mathrm{V}$ ． 結語——EU 法の変容の可能性}

ユーロ危機・難民危機に対して，EUは，EUに権限をより集中させる集権 的対応を構想しており，それが実現すれば EUの権限はより強化される。しか し，両危機への対応措置により，また危機に起因する部分が大きい加盟国の国 内政治状況の変化により，依然として一般的には堅実に機能している EU 法の 
『日本 $\mathrm{EU}$ 学会年報』第38号, 平成30年 4 月

基礎を掘り崩しかねないような別の事態が $\mathrm{EU}$ 法に関連して進行していること にも注意する必要がある。それが第一に，ユーロ危機対応措置に見られる， $\mathrm{EU}$ の中核部分である EMU に関する EU 法と国際法の結合であり，第二に， 難民危機対応措置に見られる, 加盟国の EU 法上の義務の履行への抵抗と, 難 民危機を背景に進行した中東欧諸国における $\mathrm{EU}$ の基本的価值からの逸脱であ る。前者は, 理論的に, EU 法の高い実効性を支える EU 法と国際法の区別を 相対化し，後者は，実際的に，EU 法を国際法から区別している EU 法の実効 性の高さに不安を抱かせる。

$\mathrm{EU}$ を確固として支えてきた EU 法は，EU 司法裁判所が公式に表明した認 識とは別に，国際法の要素を多く含んだ，特殊な法秩序である。 EU 司法裁判 所は, EUの欧州人権条約加入について判断した, 2014年12月の意見 2/13 が そうであるように，EU 法秩序の自律性（autonomy）を強調しがちであるが, 自律性の強調は, 国家法に比した場合に明らかな EU 法の脆弱性の裹返しと言 えなくもない。1990年代初頭, Joseph Weiler は, EU 法の優位を始めとする, $\mathrm{EU}$ 司法裁判所が確立した諸原則の結果として生じた $\mathrm{EU}$ 法の変容を「共同体 法構造の立憲化」と説明し, 国際法から切り離された $\mathrm{EU}$ 法秩序像を打ち立て て, EU 法の理論と実務に大きな影響を与えた。他方, 本稿で検討した EU 法 について生じた変化は, 立憲化とは逆方向への EU 法の変容を意味しているよ うに思われる。しかし, このことを, 単純に EU 法の国際法への回帰と理解す ることも妥当ではなからう。危機の中でも，EU 法の全般的な実効性は未だ損 なわれてはいないからである。もっとも, ユーロ危機対応措置の場合も難民危 機対応措置の場合も, 事態はなお流動的であり, 進行しつつある変化が短期的 に終息し，従来の状態に復帰するのか，それとも永続化するのか定かではない。 そもそも，EU 司法裁判所が，1960年代から1970年代という初期に下した判例 には，誕生したばかりの自己の存在を確立するために，EU 法の独自性を過度 に強調した嫌いがある。今後の推移を注視する必要があるが, 事態の進行如何 によっては，それらの判例に依拠した $\mathrm{EU}$ 法秩序像の再定義が必要となるかも 
しれない。それだけの可能性を内包した，EU 法にとって重大な事態が現在進 行しているというのが，本稿の認識である。

なお，本稿は，中東欧諸国のうちハンガリーとポーランドだけを検討したが， ルーマニアでも立憲主義の危機が進行していることを付言する。これら中東欧 諸国の動向は，EUの将来像にも影響しかねない。基本的価值の理解につき新 たに加盟した中東欧諸国と従来の加盟国との間に分断が生じれば，「異なる速 度による欧州統合」を支持する要素となり得るからである。

以上

1 ） 遠藤乾『欧州複合危機』（中公新書，2016年） ii-iv 頁，危機の諸側面は，以下の邦語文献に よる。田中素香『ユーロ危機とギリシャ反乱』(岩波新書, 2016年), 墓田桂『難民問題一イス ラム圈の動摇, $\mathrm{EU}$ の苦恼, 日本の課題』(中公新書, 2016年), 伊藤さゆり『EU 分裂と世界 経済危機一イギリス離脱は何をもたらすか』(NHK 出版新書, 2016年), 庄司克宏『欧州の危 機, Brexit ショック』(東洋経済新報社・2016年)。

2 ）水島治郎『ポピュリズムとは何か一民主主義の敵か, 改革の希望か』(中公新書, 2016年)。

3 ) Commission, Standard Eurobarometer 86, Autumn 2016, Public Opinion in the European Union, First results 15 (November 2016).

4) ジャック・サピール（坂口明義訳）『EU 崩壊一秩序ある脱＝世界化への道』（藤原書店, 2017年)，エマニュエル・トッド（堀茂樹訳）『問題は英国ではない，EUなのだ一 21 世紀の新 国家論』(文春新書，2016年），木村正人『EU 崩壊』(新潮新書，2013年）ほか多数。

5 ) Case 26/62 Van Gend en Loos v. Netherlandse Administratie der Belastingen, [1963] ECR1，12; 中村民雄 - 須網隆夫編著『EU 法基本判例集 [第 2 版]』5 頁（日本評論社 · 2010 年)。

6 ) Case 6/64 Costa v. ENEL, [1964]ECR585, 593-594; 中村·須網，前揭注 5 ）16頁。

7 ) Case 294/83 Parti écologiste 'Les Verts' v. European parliament, [1986]ECR1339, para. 23 ; 中村 ·須網, 前揭注 5 ) 150 頁。

8 ) Opinion 1/91, Draft agreement between the Community, on the one hand, and the countries of the European Free Trade Association, on the other, relating to the creation of the European Economic Area, [1991]ECR I-6079, para. 21.

9） 2008 年の Kadi 事件判決は, 基本的憲法的憲章である EC 条約を頂点とする EC 法制度の自 律性を強調し (Joined Cases C-402/05 P and C-415/05 P Kadi and Al Barakaat International Foundation v. Council and Commission, [2008]ECR I-6351, paras. 281-282), 2011年 の意見1/09号も，EU 基本条約が通常の国際条約とは異なり，新しい法秩序を確立したこと， 
『日本 $\mathrm{EU}$ 学会年報』第38号, 平成30年 4 月

加盟国がそのために自己の主権的権利を制限したこと，EU 法秩序の本質が加盟国法に対する 優位と直接効果にあること, EU 法秩序の自律性を尊重すべきことを，それぞれ明示した (Opinion 1/09 Draft agreement on the European and Community Patent Court, 8 March 2011, paras. 65-67)。

10) Damian Chalmers, Christos Hadjiemmanuil, Giorgio Monti and Adam Tomkins, European Union Law, Text and Materials 51-57 (2006); Koen Lenaerts and Piet Van Nuffel, European Union Law 16-24 ( $3^{\text {rd }}$ ed. by Robert Bray and Nathan Cambien, 2011).

11）須網隆夫「EU 法という新しい法体系, $\mathrm{EU}$ 法を知らずに $\mathrm{EU}$, そして世界を理解できるの か」小久保康之編『EU 統合を読む一現代ヨーロッパを理解するための基礎』(春風社, 2016 年) 110-140頁。

12) Karen J. Alter, Establishing the Supremacy of European Law, The Making of an international Rule of Law in Europe (2001).

13）伊藤洋一「EC 法の国内法に対する優越(1)」法学教室264号（2002年）109-110頁。

14) Frontini v. Ministero delle Finanze, [1974] 2 CMLR 372, Granital v. Ammistrazione delle Finanze dello Stato, 21 CMLRev. 756-772 (1984).

15) Paul Craig and Gráinne De Burca, EU Law, Text, Cases, and Materials 268-296 (Fifth ed., 2011).

16) Damian Chalmers, Gareth Davies and Giorgio Monti, European Union Law 188-201 (2nd ed., 2010).

17) Trevor C. Hartley, Constitutional Problems of the European Union 123-148 (1999).

18) Trevor C. Hartley, The constitutional foundations of the European Union, Law Quarterly Review, 117, 225, 233-234 and 245-246 (2001); 最近の類似の見解として, Bruno de Witte, EU Law: is it international law?, in European Union Law 174-195 (Catherine Barnard and Steeve Peers eds., 2014) がある。

19) $I d$. at $225-226$.

20) Charlmers, Hadjiemmanuil, Monti and Tomkins, supra note 10 , at $52-53$.

21) Chalmers, Davies and Monti, supra note 16, at 206-209.

22）須網隆夫「ヨーロッパに扔ける憲法多元主義一非階層的な法秩序像の誕生と発展」法律時報 85卷11号（2013年） 43-48頁。

23）須網隆夫「EU 法と国際法一多元的な法秩序観と EU 法秩序の性質」福田耕治編『多元化す る $\mathrm{EU}$ ガバナンス』(早大出版部・2011年） 7 -37頁。

24）須網隆夫「グローバル立憲主義とヨーロッパ法秩序の多元性一EU の憲法多元主義からグロ ーバル立憲主義へ一」国際法外交雑誌113卷 3 号（2014年）38(338)-51(351) 頁。

25) Jacques Pelkmans, Designing a Genuine EMU, which 'Unions' for EU and Eurozone?, 日本 $\mathrm{EU}$ 学会年報第34号 (2014年) 27頁。

26）須網隆夫「EU 複合危機と $\mathrm{EU}$ 法一ユーロ危機・難民危機・Brexit と EU 法の変化一」ロ ー・アンド・プラクティス（2017年） 5 -13頁。

27) Edoardo Chiti and Pedro Gustavo Teixeira, The Constitutional Implications of the Euro- 
pean Responses to the Financial and Public Debt Crisis, 50 CMLRev. 683, 685-686 (2013).

28）恒久的な財政援助メカニズムの設立と TFEU 125 条の整合性に疑問が生じ，そこから基本条 約の改正が浮上し (Alberto de Gregorio Merino, Legal Developments in the Economic and Monetary Union during the Debt Crisis: The Mechanism of Financial Assistance, 49 CMLRev. 1613，1628（2012）），簡易改正手続（TEU 48条 6 項）に従った，2011年 3 月の欧州 理事会決定（Decision 2011/199/EU）により，欧州安定メカニズムの設立を，ユーロ圈加盟 国に認める規定が TFEUに挿入され（136条 3 項），その後 ESM 条約が調印された。

29）同協定は，欧州理事会決議と二つの理事会規則（「財政状況の監視と経済政策の監視・調整 の強化に関する規則 (多角的監視手続強化規則)」と「過剩な財政赤字手続実施の迅速化と明 確化に関する規則（迅速化・明確化規則）」）により構成され，加盟国の財政状況を監視して， 過剩な財政赤字の発生を防止し，一旦過剩赤字が発生した場合は，その是正のため，基本条約 の内容を政治的・法的に補完していた（須網隆夫「欧州経済通貨同盟の法的側面」早稲田法学 74 卷 4 号（1999年）123-130頁，久保広正「ユーロ危機と EU の将来」日本 EU 学会年報第34 号（2014年） $2-3$ 頁)。但し, 安定成長協定による財政規律の厳格さは, 2003年以降, 理事会 が政治的に緩和し，それに欧州司法裁判所が一定の歯止めをかけていた（須網隆夫「過剩財政 赤字手続の意義」貿易と関税53巻 3 号（2005年） 75(1)-69(7)頁)。

30）須網・前掲注26） $7-8$ 頁。

31）中西優美子「EU 債務危機と法制度的対応」時の法令1903号（2012年）74頁，庄司克宏 $\lceil\mathrm{EU}$ 財政条約とユーロ危機一「二速度式欧州」と欧州統合の行方一」貿易と関税 60 巻 3 号 (2012年) 26頁。

32） EC 条約 293 条は, 幾つかの事項について加盟国間の交涉を規定し, 旧 $\mathrm{EU}$ 条約 34 条 2 項も, 警察・刑事司法の領域で, 加盟国間に扔ける条約（conventions）締結を予定していた。

33) Lenaerts and Van Nuffel, supra note 10, at 928-929.

34) Chiti and Gustavo Teixeria, supra note 27, at 686-687; Steve Peers, Towards a New Form of EU Law ?: The Use of EU Institutions outside the EU Legal Framework, 9 EuConst 37, 38 (2013).

35) Paul Craig, Pringle and Use of EU Institutions outside the EU Legal Framework: Foundations, Procedure and Substance, 9 EuConst 263, 263-284 (2013).

36) Peers, supra note 34 , at $42-44$.

37) Id. at $40-41$ and 72 .

38）第一は, 財政条約の対象事項を規制するのに, 「基本条約の改正」又は「補強化協力」とい う手段を利用せずに，国際条約という形式を採用したことの是非であり，第二に，財政条約と 基本条約の整合性が担保されているかである（須網・前掲注26）20-23頁)。

39）須網・前掲注26）23-24頁。

40）財政条約は，第一に，加盟国に，政府予算の均衡·黒字を義務付けている（3 条 1 項 a)。 具体的には，政府債務の対 GDP 比が $60 \%$ を越える国は，毎年の財政赤字をGDP の $0.5 \%$ 以内 に，60\%以下の国は 1 \%以下に抑えることが義務付けられる（3 条 1 項 $\mathrm{b} \cdot \mathrm{d})$ 。第二は，赤字 是正措置であり, 加盟国が目標から逸脱すると，欧州委員会が定める原則に基づいて修正を求 
『日本 $\mathrm{EU}$ 学会年報』第38号, 平成30年 4 月

める, 是正メカニズムか自動的に発動される (3 条 1 項 $\mathrm{e})$ 。第三に, GDP の $60 \%$ を越える政 府債務につき，加盟国は，毎年20分の 1 の削減を義務付けられる (4 条)。例えば, 第一につ いて定められた具体的基準は, 従来の安定成長協定には含まれていない（中西・前掲注31）75

頁)。したがって，財政条約締約国は，EU 法以上の義務を国際法上負ったことになる。

41） $\mathrm{EU}$ 法上の義務に加え，かつ $\mathrm{EU}$ 法上の義務を害してはならないと規定している（財政条約 3 条 1 項）(庄司・前揭注31）28頁)。

42）このような $\mathrm{EU}$ 司法裁判所の関与は, 前述の TFEU 273 条（加盟国間の特別な合意に基づく 司法裁判所の管轄権の設定）を根拠条文としている。

43）そのためシェンゲン条約では, 内容的にも, EC との関倸は正面に出てこない。但し, シェ ンゲン実施条約（1990年）は，EC 法との関係に言及している(同条約134条)。

44) Dariusz Adammski, Economic Constitution of The Euro Area After The Gauweiler Preliminary Ruling, 52 CMLRev. 1451，1486-1487 (2015); 中村民雄「ユーロ危機対応と EU 立 憲主義」日本 EU 学会年報第34号128-154頁 (2014年)。

45) Michael Ioanidis, Europe's New Transformations: How The EU Economic Constitution Changed During The Eurozone Crisis, 53 CMLRev. 1237, 1241-1243 and 1248 (2016); Chiti と Teixeria は, 前述の憲法的変容につき, 以下の懸念を指摘する。第一に, ユーロ圈が, 特別な形態の政府間主義に傾斜することは EU システム全体の一貫性を衰失させ, EU を断片 化させる (Chiti and Gustavo Teixeria, supra note 27, at 706)。第二に, 政府間主義の拡大 により，EU 政体の民主的正統性が弱体化する（Id., at 706-707）。第三に, 相互利益のための

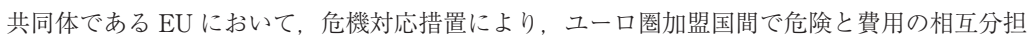
が進められたことは, 各国の短期的利益には結びつかず, $\mathrm{EU}$ の求心力を損ないかねない (Id. at $707-708)$ 。

46) Chiti and Gustavo Teixeira, supra note 27, at 704.

47) $I d$. at 695.

48) Takao Suami, EU Law, EEA Law and International Law-The Myth of Supranational Law and Its Implications for International Law, in The EEA and the EFTA Court 529, 537-538 (The EFTA Court ed., 2014); 須網隆夫「EEA 法の法的性質一EU 法 · EEA 法 · 国 際法」法時85巻 8 号 (2013年) 61-66頁。

49）須網・前掲注23）25-28頁。

50）同·11-16頁。

51) Chiti and Gustavo Teixeira, supra note 27, at 693; Scicluna は, 危機対応の中で, 加盟国 行政権の優越が強化されているとの認識から，EU 法秩序の超国家性の低下と国際法化を指摘 している (Nicole Scicluna, European Union Constitutionalism in Crisis 123 and 127 (2015))。

52) Editorial comments, Union membership in times of crisis, 51 CMLRev. 1, 2-3 (2014).

53）例えば，現在のドイツ基本法は， EUへの加盟（23条）と国際組織一般への加入（24条）を 区別している。また加盟国の憲法裁判所は，ポーランドのような例外もあり，各国ごとに微妙 に異なってはいるが, 一般に, 国内憲法に対する $\mathrm{EU}$ 法の優位を全面的には認めないものの, 
他方では EU 法を通常の国際法とは区別された超国家法であり，加盟国法秩序はそのような $\mathrm{EU}$ 法秩序と深く結びついていると認識している(須網・前掲注23）12-16頁)。

54）欧州政治協力（EPC），欧州通貨制度（EMS），シェンゲン協定等を例示することができる。

55）遠藤・前掲注 1 ） 34-40頁，墓田・前掲注 1 ） 67-74頁，八十田博人「地中海移民·難民対策 をめぐるイタリア・EU 間の論争」日本 $\mathrm{EU}$ 学会年報第37号（2017年）73-74頁。

56）墓田・前揭注 1 ） 84-85頁。

57) Convention determining the State responsible for examining applications for asylum lodged in one of the Member States of the European Communities, OJ 1997, C 254/1; 中 坂恵美子『難民問題と『連帯』一EUのダブリン・システムと地域保護プログラム』（東信 堂・2010年）39-51頁，佐藤以久子「EU 庇護立法の進展一ダブリン規則一」 EU 法研究第 3 号 (2017年) 38-71頁。

58) Regulation (EU) No 604/2013 of the European Parliament and the Council of 26 June 2013 establishing the criteria and mechanisms for determining the Member State responsible for examining an application for international protection lodged in one of the Member States by a third-country national or a stateless person (recast), OJ 2013, L 180/31.

59）ダブリン・システムは，不法に域外国境を越えた庇護申請者に，最初に入国した加盟国での 申請を義務付けるとともに，その国で申請しなかった者を不法移民として送還手続の対象とす るが，全ての加盟国が域外第三国と国境を接してはいないので，加盟国への影響は一様でなく， 一部の加盟国に庇護申請審査の負担が集中する（中坂・前掲注57）95-106頁)。加盟国間の非 対称性は当初より認識されており，そうであるから TFEU 80条は，加盟国間の「連帯と責任 の公正な分担」による非対称性への対応を規定していた（Galina Cornelisse, What's Wrong With Schengen?, Border Disputes and The Nature of Integration in The Area Without Internal Borders, 51 CMLRev. 741, 757-758 and 768 (2014))。

60) Maarten Den Heijer, Jorrit Rijpma and Thomas Spijkerboer, Coercion, Prohibition, and Great Expectations: The Continuing Failure of the Common European Asylum System, 53 CMLRev. 607-642 (2016).

61）欧州委員会は，特定の加盟国に申請が集中した場合に適用される，他の加盟国への配分メカ ニズムを盛り込んだダブリン III 規則の改正に加え, 従来の「指令」による加盟国法の調和が, 加盟国ごとに庇護申請者の取扱いが異なる一因であったとの認識から，主な 3 指令（資格指 令・庇護手続指令・受入処遇指令）の「規則」による代替を提案している (Commission, Communication from the Commission to the European Parliament and the Council, Towards a Reform of the Common European Asylum System and Enhanced Legal Avenues to Europe, $\operatorname{COM}(2016) 197$ final, 6 April 2016; Commission, Proposal for a Regulation of the European Parliament and of the Council establishing the criteria and mechanism for determining the Member State responsible for examining an application for international protection lodged in one of the Member States by a third-country national or a stateless person, $\operatorname{COM}(2016) 270$ final, 4 May 2016)。

62) European Council, Conclusions (EUCO 22/15), Brussels, 26 June 2015. 
『日本 $\mathrm{EU}$ 学会年報』第38号, 平成30年 4 月

63) Council Decision (EU) 2015/1523 of 14 September 2015 establishing provisional measures in the area of international protection for the benefit of Italy and of Greece, OJ 2015, L 239/146.

64) Council Decision (EU) 2015/1601 of 22 September 2015 establishing provisional measures in the area of international protection for the benefit of Italy and Greece, OJ 2015, L 248/80; な㧍, オーストリアへの割当人数の一部は, その後暫定的に停止させられている (Council Implementing Decision (EU) 2016/408 of 10 March 2016 on the temporary suspension of the relocation of $30 \%$ of applicants allocated to Austria under Decision (EU) 2015/1061 establishing provisional measures in the area of international protection for the benefit of Italy and Greece, OJ 2016, L 74/36)。なおオーストリアは, 2017年 3 月に停止期 間の延長を申請したが, 欧州委員会は延長を認めなかった。また, 全体の難民数は, トルコ在 住のシリア難民の受入れ開始に対応し，2016年 9 月の決定により引き下げられている（Council Decision (EU) 2016/1754 of 29 September 2016 amending Decision (EU) 2015/1601 establishing provisional measures in the area of international protection for the benefit of Italy and Greece, OJ 2016, L 268/82)。

65) Den Heijer, Rijpma and Spijkerboer, supra note 60, at 629.

66) Editorial comments, From eurocrisis to asylum and migration crisis: Some legal and institutional considerations about the EU's current struggles, 52 CMLRev. 1437, 1441-1442 (2016).

67）同決定の根拠は, TFEU 78 条 3 項であり, 同項は, 第三国からの入国の急増という緊急事 態に特定の加盟国が直面した場合に, 理事会が委員会提案に基づき, 暫定措置を取ることがで きることを定めている。同項は, 理事会の決定要件を規定していないので, 原則に従い特定多 数決により決定される (TEU 16条 3 項)。

68) Editorial comments, supra note 66, at 1448.

69）両国政府は，様々な法的主張を展開して，決定の無効を根拠付けている。第一に，ハンガリ 一政府は, 決定の根拠である TFEU 78 条 3 項は, 立法行為であるダブリン規則の例外を定め る措置の根拠条文とはならないこと, 決定の 24 か月の適用期間（13条 2 項）は, 78 条 3 項の 「暫定措置」の概念と矛盾すること, 委員会提案の変更は, 全会一致でなされねばならなかっ たことなどを主張した（Case C-647/15 Hungary v. Council）。第二に，スロバキア政府は， 欧州理事会と他の $\mathrm{EU}$ 機関との権限配分（TFEU 68条·13条 2 項）と EU 機関間均衡の違反, 決定の性質は立法であるので78条 3 項を根拠にはできないこと, 決定手続の違反等を主張した (Case C-643/15 Slovakia v. Council)。

70) Kees Groenendijk and Boldizar Nagy, The Hungarian Parliament adopts an Act calling for a review of the legality of Council Decision (EU) 2015/1601 (December 2015) (http://eumigrationlawblog.eu/hungarys-appeal-against-relocation-to-the-cjeu-upfront-attackor-rear-guard-battle/).

71) Commission, Report from the Commission to the European Parliament, the European Council and the Council, Thirteenth report on relocation and resettlement, COM(2017) 
330 final, 13 June 2017, 1-9; Commission, Report from the Commission to the European Parliament, the European Council and the Council, Fourteenth report on relocation and resettlement, 26 July 2017, 1-11.

72) Commission, Thirteenth report, supra note 71 , at 3 and 9.

73) Commission, Relocation: Commission launches infringement procedures against the Czeck Republic, Hungary and Poland, Press release, 14 June 2017.

74) Commission, Thirteenth report, supra note 71.

75) Commission, Relocation: Commission moves to next stage in infringement procedures against the Czech Republic, Hungary and Poland, Press release (IP/17/1607), 26 July 2017.

76) Joined Cases C-543/15 and C-647/15 Slovak Republic, Hungary v. Council, 6 September 2017.

77) Commission, Relocation: Commission refers the Czech Republic, Hungary and Poland to the Count of Justice, Press release (IP/17/5002), 7 December 2017; Case C-715/117 Commission v. Poland, Case C-718/17 Commission v. Hungary, Case C-719/17 Commission v. Czech Republic.

78）小野義典「ハンガリー基本法」憲法論叢18号（2011年）159-214頁, 早川弘道「ハンガリー 議会政の史的考察一体制転換期における議会制民主主義再建への道程」早稲田大学比較法研究 所編『日本法のアイデンティティに関する総合的・比較法的研究一源流の法とグローバル化の 法一』（成文堂·2006年） 114-142頁，水島朝穂・佐藤史人「試練に立つ立憲主義？－2011年 ハンガリー新憲法の「衝撃」(1)」比較法学46卷 3 号 (2013年) 39-83頁,「同(2) ·完)」比較法 学47巻 1 号（2013年）1-52頁, Editorial Comments, Hungary's new constitutional order and "European unity”, 49 CMLRev. 871-884 (2012); Kriszta Kovács and Gábor Attila Tóth, Hungary's Constitutional Transformation, 7 EuConst 183-203 (2011).

79）須網隆夫「欧州連合（EU）拡大と法の継受一拡大に対する新加盟国の対応一」早稲田大学 比較法研究所 · 前揭注78）47-69頁。

80) Marton Varju and Flora Fazekas, The Reception of European Union Law in Hungary: The Constitutional Court and the Hungarian Judiciary, 48 CMLRev. 1945, 1953 and 19561957 (2011); László Sólyom, The Rise and Decline of Constitutional Culture in Hungary, in Constitutional Crisis in the European Constitutional Area, Theory, Law and Politics in Hungary and Romania 12-17 (Armin von Bogdandy and Pál Sonnevend eds., 2015).

81) Varju and Fazekas, supra note 80, at 1964-1966.

82）佐藤史人「憲法改正権力の活躍する「立憲主義」」世界2016年11月号156頁。

83）ハンガリー基本法 $\mathrm{S}$ 条 2 項は, 新たな基本法の採択又は基本法の改正は, 国会の総議員の 3 分の 2 以上の賛成を必要とすると規定している。

84）新憲法は，その後採択された基本法に関連する「暫定条項（Transitional Provisions of the Basic Law of Hungary)」(補則 3 項）（基本法の一部）とともに，2012年 1 月より施行された。 新斝法もその後2013年 9 月の第五次改正に至るまで 5 回に渡り改正されている (Pál Sonne- 
『日本 $\mathrm{EU}$ 学会年報』第38号, 平成30年 4 月

vend, András Jakab and Lóránt Csink, The Constitution as an Instrument of Everyday Party Politics: The Basic Law of Hungary, in Constitutional Crisis in the European Constitutional Area, supra note 80, at 33, 52-63)。

85）ガボア・ポリヤック（鈴木秀美訳）「ハンガリーのメディア規制の危機的問題」メディア . コミュニケーション67号149-159頁 (2017年); Sólyom, supra note 80, at 17-29.

86) Bojan Bugarič, Protecting Democracy and the Rule of Law in the European Union: The Hungarian Challenge, LEQS paper No.79/2014, 8 (July 2014); 佐藤·前揭注82) 156-164頁。

87) Venice Commission, Opinion on the New Constitution of Hungary (Opinion no. 618/2011), 20 June 2011, paras. 89-97; 憲法裁判所が, 予算・税法の合憲性に対する審査権 限を制限され ( $I d$. p para. 98), 審査理由が特定の人権に照らした審査に限定されたことは基本 権保護を損う (Venice Commission, Opinion on the Fourth Amendment to the Fundamental Law of Hungary (Opinion 720/2013), 17 June 2013, para. 110)。 ; Sólyom, supra note 80, at 21-23; Sonnevend, Jakab and Csink, supra note 84 , at 92-96.

88) Venice Commission, Opinion no. 618/2011, supra note 87, para. 108; Sonnevend, Jakab and Csink, supra note 84, at 98-107; なおハンガリー憲法裁判所は, 2012年 7 月 16 日判決 (Judgment no. 33/2012. (VII. 17) AB of the Constitutional Court) で, 急激な定年引き下 げを違憲と判断した (Venice Commission, Opinion on the Cardinal Acts on the Judiciary that were amended following the adoption of Opinion CDL-AD(2012)001 on Hungary (Opinion no. 683/2012), 15 October 2012, para. 75)。これにより, 新たに65才の定年を定め る立法が制定され, 辞めさせられた裁判官の復帰が実現し, 欧州委員会も義務違反手続を終了 させた (Frank Hoffmeister, Enforcing the EU Charter of Fundamental Rights in Member States: How Far are Rome, Budapest and Bucharest from Brussels?, in Constitutional Crisis in the European Constitutional Area, supra note 80, at 195, 214-216)。

89) Baka v. Hungary [GC] no. 20261/12, 23 June 2016.

90) Joakim Nergelius, The Role of the Venice Commission in Maintaining the Rule of Law in Hungary and in Romania, in Constitutional Crisis in the European Constitutional Area, supra note 80, at 291, 296-301; Venice Commission, Opinion 720/2013, supra note 87, paras. 78-87; Sólyom, supra note 80 , at 19-21 and 25-27; Sonnevend, Jakab and Csink, supra note 84 , at 57 .

91) Venice Commission, Opinion on the Legal Questions Arising in the Process of Drafting the New Constitution of Hungary (Opinion no. 614/2011), 28 March 2011; Venice Commission, Opinion no. 618/2011, supra note 87; Venice Commission, Opinion on Act CLXII of 2011 on the Legal Status and Remuneration of Judges and Act CLXI of 2011 on the Organization and Administration of Courts of Hungary (Opinion 663/2012), 19 March 2012; Venice Commission, Opinion on Act CLI of 2011 on the Constitutional Court of Hungary (Opinion no. 665/2012), 19 June 2012; Venice Commission, Opinion no. 683/2012, supra note 88; Venice Commission, Opinion on Act CXII of 2011 on Informational Self-determination and Freedom of Information of Hungary (Opinion 672/2012), 18 October 
2012; Venice Commission, Opinion 720/2013, supra note 87; Venice Commission, Opinion on Media Legislation (Opinion no. 798/2015), 22 June 2015; もちろんハンガリー国内には, ベニス委員会に批判的な見解もある (András Jakab and Pál Sonnevend, Continuity with Deficiencies: The New Basic Law of Hungary, 9 EuConst 102-138 (2013))。

92) Venice Commission, Opinion 663/2012, supra note 91, para. 120; 欧州人権裁判所も, この 間，ハンガリーの人権条約違反を認定する判決を下している。例えば，人権裁判所小法廷は,

2017年 3 月，ハンガリーの難民収容の現状を違法とする判決を下した（Case of Ilias and Ahmed v. Hungary, Application no. 47287/15, 14 March 2017)。なお大法廷は, 上訴を受理 している (European Court of Human Rights, Press Release, ECHR 282 (19 September 2017))。

93) Committee of Ministers, Council of Europe, H46-15 Baka v. Hungary (Application No. 20261/12), Supervision of the execution of the European Court's judgments (7-10 March 2017).

94）例えば, 通常裁判所裁判官の任命について, ベニス委員会の意見の大半が採用されたとの意 見もあるが (Sonnevend, Jakab and Csink, supra note 84, at 100)，他方でEU 及び欧州審 議会の影響力は，本質的部分については，ほとんどなかったと評価する者もいる(ポリヤッ ク・前掲注85）156-158頁)。な㧍, ベニス委員会が批判した，国家司法庁（National Judicial Office）による訴訟事件の別の裁判所への移送も, 基本法第五次修正によって廃止された（Sonnevend, Jakab and Csink, supra note 84, at 101-102)。

95) European Parliament resolution of 5 July 2011 on the Revised Hungarian Constitution; 例えば，前述の裁判官の定年引き下げに対して，欧州委員会は，年齢差別を禁止する雇用機会 均等指令2000/78号違反を理由に義務違反訴訟を提起し, EU 司法裁判所は, ハンガリーの義 務違反を認定し (Case C-286/12 Commission v. Hungary, 6 November 2012), ハンガリー は法改正で対応している (Sonnevend, Jakab and Csink, supra note 84, at 106-107; Hoffmeister, supra note 88, at 214-216)。個人情報保護及び情報公開法を改正して, 個人情報保 護監督官を任期途中で交代させたことについても，委員会は，指令 $95 / 46$ 号が定める個人情報 保護機関の独立性の違反として，義務違反訴訟を提起し，違反が認定されている（Case C-288/82 Commission v. Hungary, 8 April 2014)。

96) Commission, Infringements-Hungary: Commission launches infringement procedure for law on foreign-funded NGOs, Press release (IP/17/1982), 13 July 2017.

97) Editorial comments, supra note 52, at 1-12.

98）須網·前掲注79）53-53頁。

99) Armin Von Bogdandy and Michael Ioannidis, Systemic Deficiency in the Rule of Law: What It Is, What Had Been Done, What Can Be Done, 51 CMLRev. 59-96 (2014); Bugarič, supra note 86, at 14-17; 欧州委員会は, 2003年に, TEU 7 条の適用要件を明確化して いる (Commission, Communication from the Commission to the Council and the European parliament on Article 7 of the Treaty on European Union. Respect for and promotion of the values on which the Union is based, $\operatorname{COM}(2003) 606$ final)。 
『日本 $\mathrm{EU}$ 学会年報』第38号, 平成30年 4 月

100) European Parliament resolution of 17 may 2017 on the situation in Hungary (2017/2656 (RSP)), para. 9 .

101) Zoltáw Fleck and others (Andrew Arato, Gábor Halmai and János Kis eds.), Opinion on the Fundamental Law of Hungary (June 2011); Bugarič, supra note 86, at 8; Editorial Comments, The Rule of Law in the European Union, the Rule of Union Law and the Rule of Law by the Union: Three interrelated problems, 53 CMLRev. 597-606 (2016); Committee on Civil Liberties, Justice and Home Affairs (Rapporteur: Rui Travares), Report on the situation of fundamental rights: standards and practices in Hungary (pursuant to the European Parliament resolution of 16 February 2012) (24 June 2013); 既に 2012年段階で, ハンガリーは 7 条制裁手続の発動要件を満たしていたとも指摘されている (Editorial comments, Hungary's new constitutional order and “European unity”, 49 CMLRev. 877-878 (2012))。

102) Bugarič, supra note 86 , at 3-4 and 17.

103) Commission, Communication from the Commission to the European parliament and the Council, A new EU Framework to strengthen the Rule of law, $\operatorname{COM}(2014) 158$ final, 11 March 2014.

104) European Parliament resolution, supra note 100, para. 10.

105）委員会勧告は, 憲法裁判所判決の不遵守, 裁判官定足数の増加 · 決定要件の厳格化等を問題 視していたが，それに先立つべニス委員会の意見に概ね整合していた（Commission Recommendation (EU) 2016/1374 of 27 July 2016 regarding the rule of law in Poland, OJ 2016, L 217/53, paras. 72-74; Venice Commission, Opinion on Amendments to the Act of 25 June 2015 on the Constitutional Tribunal of Poland (Opinion no. 833/2015), 11 March 2016)。

106) Commission Recommendation, supra note 105, paras. 45, 50, 51 and 52.

107) Commission Recommendation (EU) 2017/146 of 21 December 2016 regarding the rule of law in Poland complementary to Commission Recommendation (EU) 2016/1374, OJ 2017 L22/65, para. (15)-(17).

108) Id. paras. $65^{-66 .}$

109) Outcome of the Council Meeting, $3536^{\text {th }}$ Council Meeting, General Affairs, 16 May 2017, 9299/17.

110) Commission Recommendation (EU) 2017/1520 of 26 July 2017 regarding the rule of law in Poland complementary to Commission Recommendations (EU) 2016/1374 and (EU) 2017/146, OJ 2017, L228/19, para. 58.

111) Commission, Reasoned Proposal in accordance with Article 7(1) of the Treaty of European Union regarding the Rule of Law in Poland, Proposal for a Council Decision on the determination of a clear risk of a serious breach by the Republic of Poland of the rule of law, $\operatorname{COM}(2017) 835$ final, 20 December 2017; Commission, Rule of Law: European Commission acts to defend judicial independence in Poland, Press release, (IP/17/5367), 20 
December 2017.

112) Commission, Commission calls for immediate suspension of logging in Poland's Biatowieza Forest, Press release (IP/17/1948), 13 July 2017; Case C-441/17 R, Commission v. Poland, 27 July 2017.

113）但し，2007年12月，ポーランド新首相 Morawiecki は，EU 司法裁判所の判断に従うことを 表明したと報じられている（https://euobserver.com/justice/140311）。

114) Commission, Report from the Commission, Monitoring the application of European Union law 2016 Annual Report, $\operatorname{COM}(2017) 370$ final, 6 July 2017; Commission, Report from the Commission, Monitoring the application of European Union law 2015 Annual Report, $\operatorname{COM}(2016) 463$ final, 15 July 2016.

115) Groenendijk and Nagy, supra note 70.

116）オルバン首相は，2014年のスピーチで，国際社会における競争力を維持するために，西欧的 価值から離れて, むしろシンガポール・中国等の開発独裁国家を模範としたリベラルではない 「非リベラル国家」を目標とする国造りを行うと宣言している（Viktor Orbán’s speech at the XXV, Bálványos Free Summer University and Youth Camp, 26 July 2014 (https:// budapestbeacon.com/full-text-of-viktor-orbans-speech-at-baile-tusnad-tusnadfurdo-of-26july-2014/)。

117）須網·前掲注11）120-127頁。

118) European Parliament resolution, supra note 100.

119) Commission, 2016 Annual Report, supra note 114; Commission, 2015 Annual Report, supra note 114.

120）須網・前揭注 26）126-127頁, Commission, Communication, supra note 61, Commission, Proposal for a Regulation, supra note 61 .

121) Opinion 2/13, Draft international agreement, Accession of the European Union to the European Convention for the Protection of Human Rights and Fundamental Freedoms, 18 December 2014.

122) J.H.H. Weiler, The Transformation of Europe, 100 Yale Law Journal, 2403-2483 (1991).

123) Bogdan Iancu, Separation of Powers and the Rule of Law in Romania: The Crisis in Concepts and Contexts, in Constitutional Crisis in the European Constitutional Area, supra note 80, at 153-169; Cosmina Tanasoiu, Romania in the European Union: Political Developments and the Rule of Law after accession, in Constitutional Crisis in the European Constitutional Area, supra note 80, at 171-190. 